\title{
Sakari Kainulainen ja Juho Saari: Suomalainen vanki
}

\author{
Villman, Emma
}

2021-05-25

Villman , E 2021 , ' Sakari Kainulainen ja Juho Saari: Suomalainen vanki ' , Kriminologia , pÿvol. 1 , nr. 1 , s. 111113 . < https://kriminologia.journal.fi/article/view/109024 >

http://hdl.handle.net/10138/330523

unspecified

publishedVersion

Downloaded from Helda, University of Helsinki institutional repository.

This is an electronic reprint of the original article.

This reprint may differ from the original in pagination and typographic detail.

Please cite the original version. 


\title{
Sakari Kainulainen ja Juho Saari: Suomalainen vanki
}

\author{
EMMA VILLMAN
}

Sakari Kainulainen \& Juho Saari (toim.): Suomalainen vanki. Vastapaino, Tampere. 2021, 318 s., ISBN 978-951-768-841-3.

Sakari Kainulainen och Juho Saari riktar i boken Suomalainen vanki (övers. den finska fången) uppmärksamheten på livskvalitet och vardagsstrukturer i finska fängelser. Boken har sin hemvist i samhällsvetenskaplig välfärdsforskning, men har tydliga inslag av klassisk fängelsesociologi, rättssociologi och kvantitativ kriminologi. Sammantaget utgör verket en varierande och innehållsrik introduktion till finska fängelseförhållanden och är ett välkommet bidrag till den finska fängelseforskningen såväl tematiskt, teoretiskt som metodologiskt. Förutom redaktörerna finns Mikko Aaltonen, Noora Ellonen, Rosi Enroos, Henrietta Grönlund, Anu Helenius, Niina Junttila, Jussi Kauhanen, Antti Kouvo, Kanerva Kuokkanen, Kati Rantala, Karoliina Suonpää samt Sasu Tyni bland bidragsgivarna.

Bokens syfte är att analysera livskvalitet och vardagsstrukturer för dömda fångar i finska fängelser. Detta forskningssyfte uppfylls väl, i synnerhet vad gäller studiet av livskvalitet. Vardagsstrukturer är ett så brett begrepp, att en bok på 300 sidor omöjligt kan täcka alla aspekter, men boken gör ett uppriktigt försök. De vardagsstrukturer som man valt att fokusera på handlar om sociala relationer, delaktighet och socialt stöd. Boken beskriver fängelsemiljön både från fångens subjektiva perspektiv och som social miljö; hur fängelsemiljön fungerar som ett socialt fält och hur fången ser på sin egen plats i förhållande till medfångar och institutionen som helhet.
Sju av bokens tolv kapitel bygger på material från forskningsprojektet VASORA (Vankila - sosiaalisen yhteisön rakenne, fritt översatt: Fängelset - den sociala gemenskapens struktur). Forskningsprojektet baserar sig på ett frågeformulär som besvarades av 443 fångar med relativt långa domar vid elva olika fängelser runtom i Finland. Undersökningens huvudsakliga tematik utgör också grunden för bokens olika kapitel; livskvalitet, upplevd hälsa, ensamhet, status, tillit, upplevd säkerhet samt socialt stöd. Bokens resterande kapitel bygger på annat finskt forskningsmaterial och behandlar fångars sociala integrering, upplevd rättvisa $\mathrm{i}$ fängelset samt fångars förhållande till sina barn. Sammantaget bidrar bokens olika kapitel till att skapa en bred bild av finska fångars subjektiva upplevelser av fängelsetillvaron. Kapitlen om fångars sociala integration (Suonpää, Ellonen, Aaltonen och Tyni) och fångarnas förhållande till sina barn (Enroos) skiljer sig från resten av boken genom sitt mera objektivt inriktade datamaterial och sina analysstrategier. Dessa båda bidrag tillför mycket viktig information på respektive område, och är ï trots att de sticker ut $\mathrm{i}$ helheten - $\mathrm{i}$ högsta grad ber-attigade i en bok med namnet òsuomalainen vankiò.

Bokens redaktörer, i likhet med många av medförfattarna, har inte sysslat med fängelseforskning tidigare. Detta är något som nämns och närmast ursäktas både i bokens inledande och avslutande kapitel. Författarnas 
utanför-blick är på många sätt bokens svaghet men också dess styrka. Att författarna $\mathrm{i}$ huvudsak arbetat inom andra forskningsfält än fängelseforskning bidrar till nya teoretiska infallsvinklar, vilket breddar den finländska fängelseforskningen. För den som känner den finska och internationella fängelseforskningen väl har boken emellanåt oväsentliga resonemang, onödigt starka generaliseringar och saknar relevant tidigare forskning. Trots detta överväger fördelarna med en utanförblick helt klart nackdelarna.

Välfärdsperspektivet är starkt i Suomalainen vanki, och som en grundton genom hela boken går frågan om hur finska fängelser upprätthåller livskvalitet och välfärd. Detta välfärdsperspektiv är välkommet, eftersom fängelset $i ̈$ sin straffande sida till trots $i ̈$ är en central välfärdsinstitution i Finland. Synen på fängelset som en välfärdsinstitution har de senaste åren växt sig starkare i den kriminologiska fängelseforskningen i Norden (Smith \& Ugelvik, 2017; Ugelvik, 2016) och därför är det viktigt att fängelset också studeras med samma metoder och utifrån samma utgångspunkter som andra välfärdsinstitutioner. Här utgör Kainulainen och Saaris bok ett ytterst viktigt bidrag. Författarnas starka samhällsvetenskapliga förankring och gedigna erfarenhet inom välfärdsforskning bidrar till att höja nivån på diskussionen om välfärd i finska fängelser. Det är framförallt när data från VASORA-undersökningen används för att göra jämförande analyser mellan fångarna och befolkningen i övrigt som viktiga insikter lyfts fram. Ett sådant exempel är kapitlet om fångarnas förtroenderelationer (Kouvo \& Saari). Kapitlet analyserar insiktsfullt partikulär och generell tillit, dvs. tillit till personer man känner i förhållande till folk i allmänhet, och jämför dessa resultat med motsvarande nationella och internationella data. Kapitlet visar att medan den generella tilliten i samhället ligger på 7,3 (på en skala från 0-10, där 0 innebär ingen tillit och 10 full tillit), så ligger fångarnas generella tillit på 4,9 ï vilket är i nivå med länder med svag tillit och utbredd korruption, som t.ex. Ryssland och Polen. Dessutom uppger en fjärdedel av fångarna att de upplever sig inte ha någon att tala med om viktiga saker i fängelset. Dessa resultat bidrar varken med förklaringar eller med lösningsförslag för hur tilliten kunde stärkas i fängelset, men utgör oerhört viktig bakgrundsinformation för att förstå finska fängelser.

I andra kapitel i boken har diskussionen inte samma kvalitet. Det kan handla om att resultatredogörelsen fastnar på en beskrivande nivå, att resultaten enbart analyseras från ett tematiskt perspektiv, eller att relevanta verktyg och teorier anpassade för analys av förhållande i en fängelsemiljö saknas. Detta finner man till exempel i det tematiskt så angelägna kapitlet om fångars ensamhet och utfrysning/ostrakism (Junttila). Kapitlet presenterar en relevant teoretisk referensram och ansenliga analyser av materialet, men eftersom kriminalitet och fängelsemiljöns påverkan inte inkluderas i tolkningen är det något som blir haltande. När fångarnas upplevelser av utfrysning dessutom jämförs med ungdomars upplevelser av utfrysning, blir det ett tecken på en otillfredsställande förståelse av fångars $\ddot{i}$ och ungdomars $\ddot{i}$ unika upplevelser av utanförskap. Också i kapitlet om fångars upplevda hälsa (Kauhanen), där fångars upplevda hälsa studeras utan att inkludera drogberoende som en variabel, aktualiseras samma problematik.

I bokens avslutande kapitel beskriver redaktör Saari verket som grundforskning snarare än som tillämpad forskning. Bokens syfte har inte varit att värdera fungerande fängelsepraxis, inte heller att ställa fångar och perso- 
nal mot varandra för att belysa de fel och brister som sker i fängelset. En sådan neutral synvinkel är viktig, men på vägen förloras kanske något av forskningens kritiska skärpa? Med undantag av Rantala, Helenius och Kuokkanens kapitel om huruvida fängelset upplevs rättvist, saknas det i stora delar av boken en kritisk udd. Man kan påstå, något som också görs i avslutningskapitlet, att fängelsekritik inte är bokens syfte, utan att ge en mera deskriptiv bild av förhållandena $i$ finska fängelser idag. Samtidigt finns det ändå tendenser i boken att främst betona fördelarna med fängelseinstitutionen. När Saari i avslutningskapitlet konstaterar att en majoritet av fångarna inte skiljer sig märkbart från resten av befolkningen beträffande livskvalitet, ensamhet och känsla av säkerhet, tolkar han det som att $\mathrm{f}$ angel seinstitutionen ơfunge rarò fo $r$ dessa personer. Men kanske dessa goda resultat, som också senare antyds i texten, snarare handlar om att fångarna anpassat sig till rådande förhållanden?

Under läsningen av boken fanns en fråga som ständigt gjorde sig påmind och som författarna inte helt klarade av att besvara: betyder välfärd innanför och utanför fängelsets murar samma sak? Och kan detta mätas utifrån samma parametrar? Djupast sett handlar denna fråga om hur vi ser på fängelset. Är fängelset en miniatyr-variant av det omgivande samhället eller är det något väsensskilt från det omgivande samhället? Suomalainen vanki utgår från den första tolkningen, och väljer att inte lägga någon vikt vid betydelsen av kontroll, övervakning och straff i studiet av livskvalitet och vardagens strukturer i fängelset. Som redan nämnts, är detta en av bokens styrkor. Frågan är samtidigt hur rättvis förståelse av fängelset man kan uppnå genom att utelämna det straffande perspektivet.
Saari och Kainulainen lyfter fram bristen på mångvetenskaplig fängelseforskning i Finland. Kritiken är befogad och deras bok är ett positivt bidrag som förhoppningsvis kan visa vägen för kommande forskning. Det behövs mera och bredare forskning om fångars förhållanden i Finland. Denna bok strävar efter att ge fångarnas subjektiva perspektiv på fängelset. Förhoppningsvis ser vi också snart forskning i Finland där inte bara forskare framfor och tolkar òf-ngamas ro-stò via fr-geformulär. Vi behöver också fängelseforskning som i högre grad involverar fångarna själva i forskningen.

Bokens namn, Suomalainen vanki, antyder att bokprojektet är ambitiöst. Boken lyckas med sitt syfte. Den är en viktig pusselbit, som bidrar till en ökad förståelse för den finska fångens livskvalitet och vardag.

\section{REFERENSER}

Smith, P. S., \& Ugelvik, T. (2017). Scandinavian Penal History, Culture and Prison Practice: Embraced by the Welfare

State? London: Palgrave Macmillan UK.

Ugelvik, T. (2016). Prisons as Welfare Institutions? Punishment and the Nordic Model. Teoksessa Y. Jewkes, B. Crewe, \& J. Bennett (toim.), Handbook on Prisons (2. painos, s. 388-402). Abingdon, Oxon: Routledge. 